\title{
Quantitative analysis of Sertoli cells in neonatally oestrogen-treated rats
}

\author{
F. Gaytan and E. Aguilar* \\ Biology Section and *Department of Physiology, School of Medicine, University of Córdoba, \\ 14071-Córdoba, Spain
}

\begin{abstract}
Summary. On Day 1 of age rats were treated with $500 \mu \mathrm{g}$ oestradiol benzoate. Oestrogen-treated rats had increased numbers of Sertoli cells per reference area or volume, whereas the total number of cells per testis was unchanged. The mean nuclear size was significantly smaller in oestrogen-treated rats than in control rats, at 22 and 45 days of age. The volume density of the heterochromatin clumps decreased from 22 to 45 days of age in control rats $(68 \%$ fall $)$, the decrease being slower in oestrogenized animals ( $30 \%$ fall) during the same period. The differences were significant at 45 days of age only. The relative volume occupied by the nuclear membrane infoldings was significantly less in oestrogenized rats than in control ones at the two ages considered. Nucleolar development was delayed in oestrogen-treated rats, which had lower numbers of nuclear sections showing nucleoli, as well as a decrease in the nucleolar diameter. We suggest that these Sertoli cell alterations are due to the altered gonadotrophin and testosterone concentrations induced by the steroid treatment rather than to a direct effect of oestrogen.
\end{abstract}

\section{Introduction}

The Sertoli cells are the primary target of FSH and androgens in the seminiferous epithelium. The presence of cellular receptors to both types of hormones has been clearly established (Parvinen, 1982; Hon et al., 1983), but the role of these hormones on the different morphological and functional aspects of Sertoli cell maturation remains unclear. During the early postnatal period, the Sertoli cells undergo mitotic divisions that cease before the 20 th day of life (Steinberger \& Steinberger, 1971; Sanborn et al., 1986), and a series of maturational changes that affect the nucleus and cytoplasm (Fawcett, 1975; Ramos \& Dym, 1979; Ritzen et al., 1981). This maturational process is dependent on gonadotrophins (Bressler, 1976; Chemes et al., 1979; Vogel et al., 1983), particularly along the LH-testosterone axis, whereas the role of FSH is dependent on the age and physiological status of the animal (Sanborn et al., 1986).

There are a great number of functional measures, such as ABP secretion (Ritzen et al., 1981), enzyme content (Sanborn et al., 1986) and the establishment of a functional blood-testis barrier (Vitale et al., 1973) that have been used to indicate the maturation index of the Sertoli cells, and exhaustive morphological studies on Sertoli cell differentiation have been carried out (Flickinger, 1967; Bressler, 1976; Ramos \& Dym, 1979).

Neonatally oestrogen-treated rats present several hormonal alterations during prepubertal development (Aguilar et al., 1984; Bellido et al., 1985), as well as an impaired maturation of various testicular cell types (Ohta \& Takasugi, 1974; Gaytan et al., 1986). The aim of this study was to quantify the effects of a single dose of oestrogen given on the first day of life on the numbers and nuclear development of Sertoli cells. 


\section{Materials and Methods}

Twenty Wistar male rats from four litters were used. The treated animals received $500 \mu \mathrm{g}$ oestradiol benzoate (Sigma Chemical Co., St Louis, MO, U.S.A.) injected subcutaneously in $0.1 \mathrm{ml}$ olive oil on the first day of life. Control animals received $0.1 \mathrm{ml}$ vehicle only. The animals were killed at 22 and 45 days of age ( 5 controls and 5 oestrogentreated rats at each age). The right testes were used for light microscopy and the remaining ones for electron microscopy.

For light microscopy the testes were fixed with Bouin's fluid for $2 \mathrm{~h}$, cut into 5-7 slices perpendicular to the longest axis of the organ and left for an additional $12 \mathrm{~h}$ in the fixative. After dehydration, the slices were embedded in paraffin wax. Sections $5 \mu \mathrm{m}$ thick were cut and stained with haematoxylin and eosin and Masson's trichrome stain.

For electron microscopy, blocks of the testes were fixed with 3\% phosphate-buffered glutaraldehyde (pH 7.3) for $1 \mathrm{~h}$, cut into smäl blocks (about $1 \mathrm{~mm}^{3}$ ) and left in the fixative overnight. These blocks were post-fixed with $1 \%$ osmium tetroxide for $2 \mathrm{~h}$ and, after dehydration in graded acetones, embedded in Araldite. Sections $1 \mu \mathrm{m}$ thick were cut with an LKB ultratome, stained with $1 \%$ toluidine blue in $1 \%$ sodium borate and observed by light microscopy. Ultrathin sections were double-stained with uranyl acetate and lead citrate and observed in a Philips 300 electron microscope. Morphometric analysis was performed at two different levels.

Level I. The numbers of Sertoli cells were determined from paraffin wax-embedded sections due to the larger area of tissue that could be analysed in this system. The testicular volume (V) was measured by the immersion method (Elias \& Hyde, 1980) in the fixed testes before cutting it into slices. Ten randomly selected sections were used per animal ( 5 slices per testis and 2 sections per slice). The volume density of the seminiferous tubules $\left(\mathrm{Vv}_{\mathbf{1}}\right)$ was determined under light microscopy with the aid of a 100-test point reticle eyepiece. The total tubular volume $\left(\mathrm{V}_{t}\right)$ was then obtained by $V v_{t} \times V$. The number of Sertoli cell nuclei per transverse tubular section $(n)$ was counted with the $\times 100$ objective, in a minimum of 50 tubular cross-sections per animal and considering only the perfectly focussed ones. The mean cross-sectional area of the same tubular sections $\left(A_{1}\right)$ was determined by point counting with the $\times 25$ objective, i.e. $A_{t}=P_{t} \cdot A_{T} / P_{T}$, where $P_{t}$ is the number of test points on the tubular profile, $A_{T}$ the test area and $P_{T}$ the total number of points. From these values we obtained the number of Sertoli cells per area unit $\left(N_{A}\right)$ by dividing $n$ by $A_{t}$. The number of Sertoli cells per unit volume of seminiferous tubules (Nv) was obtained by the Flöderus equation, $\mathrm{Nv}=\mathrm{N}_{\mathrm{A}} /(\mathrm{T}+\mathrm{D}-2 h)$, where $\mathrm{T}$ is the section thickness, $\mathrm{D}$ the mean nuclear diameter of Sertoli cells and $h$ the height of the smallest visible cap section. The values of $\mathrm{D}$ were determined by measurement of 50 Sertoli cell nuclei per animal with the aid of a micrometer eyepiece. It corresponded to the nuclear diameter parallel to the basement membrane and was $4.86 \pm 0.10 \mu \mathrm{m}$ and $6.98 \pm 0.16 \mu \mathrm{m}$ for control rats at 22 and 45 days of age respectively, and $3.54 \pm 0.17 \mu \mathrm{m}$ and $5.42 \pm 0.20 \mu \mathrm{m}$ for oestrogen-treated rats at the same ages (mean \pm s.e.m. for 5 animals per group). The value of $h$ was estimated to be equal to $0.5 \mu \mathrm{m}$, because nuclei were not taken into account below this sectional diameter (Wing \& Christensen, 1982).

The number of Sertoli cell per testis was given as $N=N v \cdot V_{1}$, where $V_{1}$ corresponded to the total tubular volume.

The percentage of nuclear sections showing nucleoli was determined by counting a minimum of 100 nuclei per animal in $1 \mu \mathrm{m}$ thick toluidine blue-stained sections. It was studied only in 45 -day-old groups because of the incomplete nucleolar development before this age even in control rats.

Level II. The Sertoli cell nuclei measurements were made on low power electron micrographs selected at random. At least 250 cell nuclei per group were studied at a final magnification of $\times 13500$. To minimize the effects of the variability amongst the different stages of the cycle in control animals (Leblond \& Clermont, 1952; Bugge \& Plöen, 1986), and amongst tubules with different degrees of damage in oestrogen-treated rats, the micrographs were taken from $20-25$ different seminiferous tubules per animal.

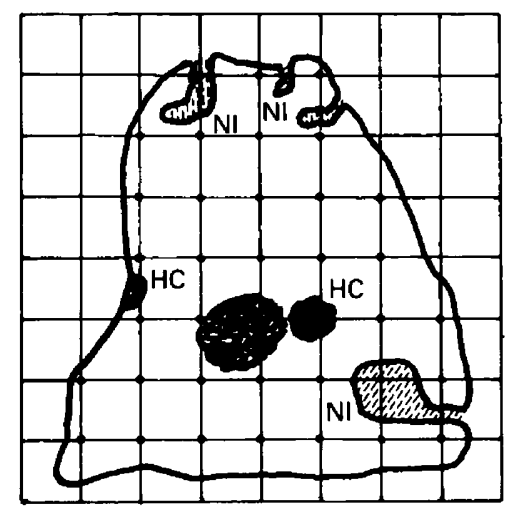

Fig. 1. Schematic drawing of a Sertoli cell nucleus and a superimposed test system. The nuclear area $(\mathrm{N})$, perinuclear heterochromatin clumps $(\mathrm{HC})$ and nuclear membrane infoldings (NI) were measured by point counting. For example, in this figure $\mathrm{P}_{\mathrm{N}}=35, \mathrm{P}_{\mathrm{HC}}=1$ and $\mathrm{P}_{\mathrm{NI}}=2$. 

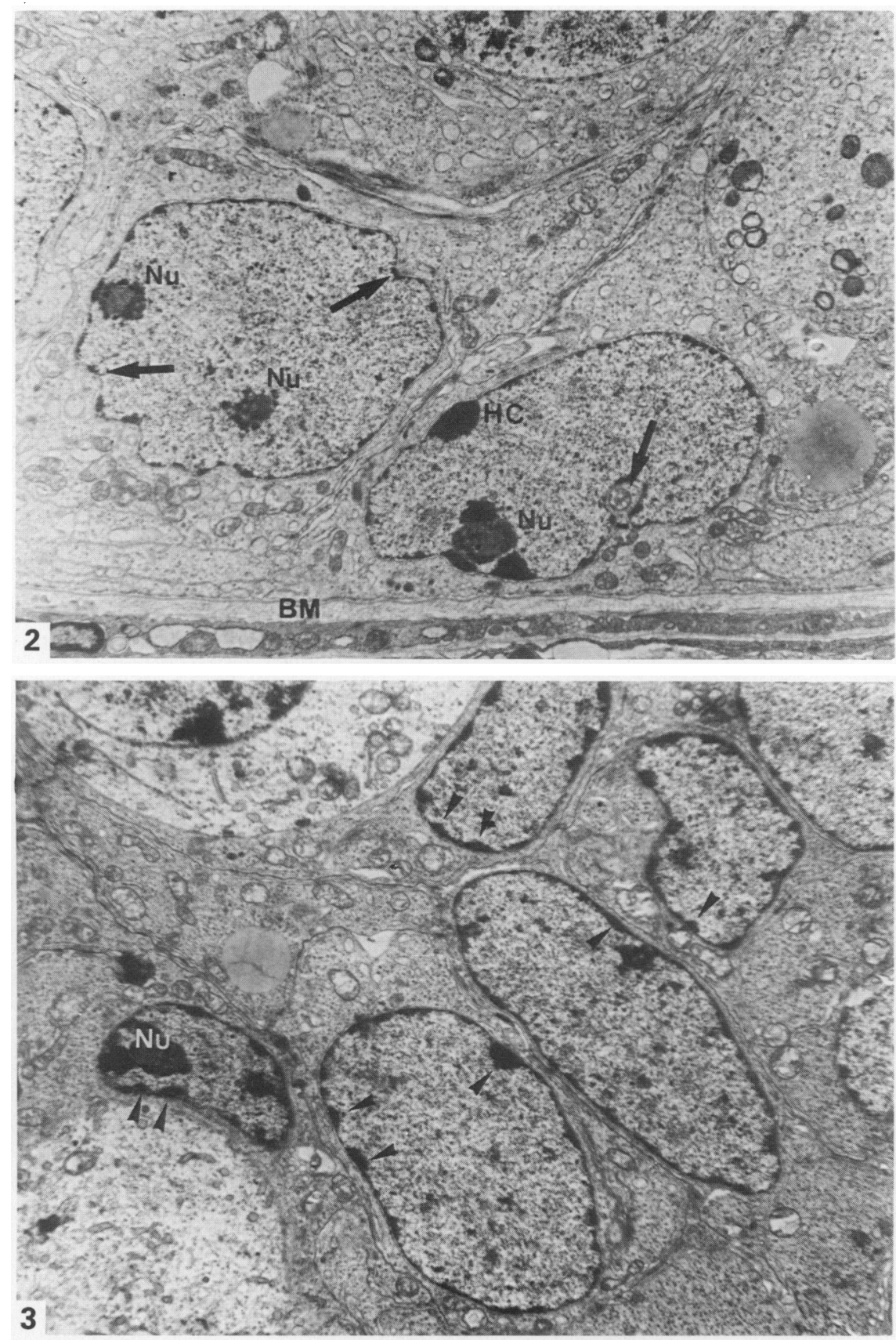

Fig. 2. Low-power electron micrograph from a 22-day-old control rat. The Sertoli cell nuclei are located near to the basement membrane (BM) and show developing nucleoli $(\mathrm{Nu})$ and heterochromatin clumps (HC). Small nuclear membrane infoldings (arrows) can be observed. $\times 8500$.

Fig. 3. Low-power electron micrograph from a 22-day-old oestrogen-treated rat. Sertoli cell nuclei are regular in outline and present heterochromatin clumps (arrowheads). Developing nucleoli $(\mathrm{Nu})$ are scarce. $\times 8500$. 

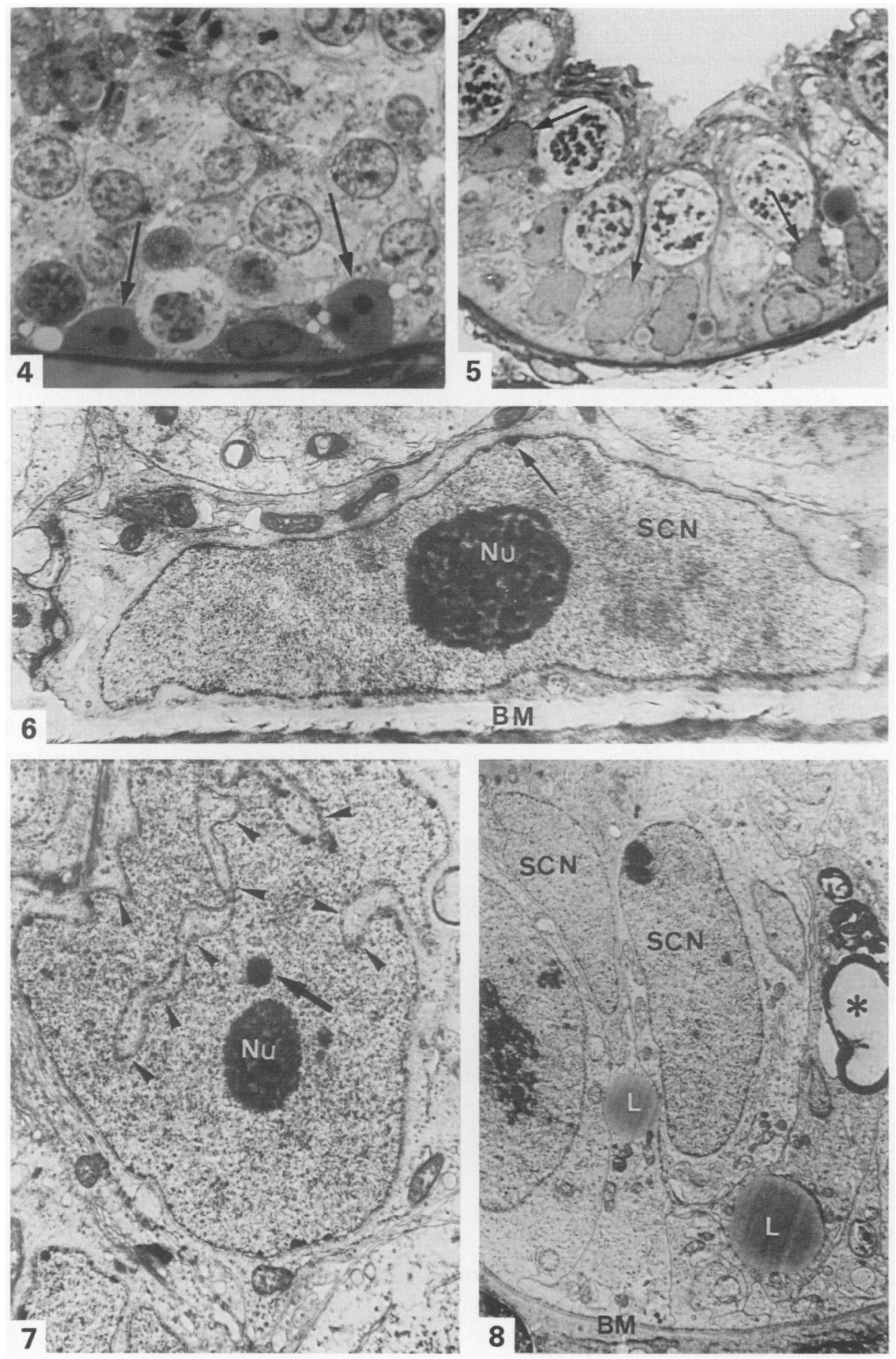

Fig. 4. Control 45-day-old rat. Semithin section stained with toluidine blue showing Sertoli cell nuclei presenting prominent nucleoli (arrows). $\times 950$.

Fig. 5. Oestrogen-treated 45-day-old rat. Most of the Sertoli cell nuclei (arrows) do not present developed nucleoli. $\times 950$. 
Using a 300-point test system superimposed on the micrographs, the number of points situated on the total nuclear profile $\left(\mathbf{P}_{\mathrm{N}}\right)$, heterochromatin clumps $\left(\mathbf{P}_{\mathrm{HC}}\right)$ and nuclear infoldings $\left(\mathrm{P}_{\mathrm{NI}}\right)$ were recorded (see Fig. 1). The mean sectional area of the Sertoli cell nuclei was obtained as the product of $\mathbf{P}_{\mathbf{N}}$ by the area corresponding to each test point $\left(\mathrm{A}_{\mathrm{T}} / \mathrm{P}_{\mathrm{T}}\right)$. The volume density of the heterochromatin clumps were obtained as $\mathrm{P}_{\mathrm{HC}} / \mathrm{P}_{\mathrm{N}}$, and the volume density of the nuclear membrane infoldings as $\mathbf{P}_{\mathrm{NI}} /\left(\mathbf{P}_{\mathrm{N}}+\mathbf{P}_{\mathrm{NI}}\right)$ and expressed as percentage. The nucleolar diameters were measured on the micrographs and the results were corrected by multiplying by $4 / \pi$.

Statistical analysis was carried out by the one-way analysis of variance and Tukey's multiple comparison method. For nucleoli the values found for control and oestrogen-treated rats were compared by Student's $t$ test. Differences were considered at the 0.05 level of significance.

\section{Results}

The morphological aspects of the seminiferous tubules in neonatally oestrogen-treated rats have been described elsewhere (Gaytan et al., 1986). Briefly, Sertoli cell nuclei in 22-day-old control rats were located at the periphery of the seminiferous epithelium and showed small nuclear membrane infoldings and a variable number of developing nucleoli, most of them associated with the perinuclear heterochromatin clumps (Fig. 2). Oestrogen-treated rats at the same age had Sertoli cell nuclei that were more elongated and regular in outline, showed a pseudostratified distribution, numerous heterochromatin clumps and a lack of nucleolar development in most cases (Fig. 3). At 45 days of age, the Sertoli cell nuclei of control rats were located close to the basement membrane, presenting fully differentiated nucleoli (Figs $4 \& 6$ ) and extensive nuclear membrane infoldings (Fig. 7). However, Sertoli cell nuclei of oestrogen-treated rats were frequently seen far from the basement membrane (Figs $5 \& 8$ ), showing a pseudostratified distribution and immature features with a lack of nuclear infoldings, increased heterochromatin clumps and nucleoli that were not well developed (Fig. 9). Some of the less affected Sertoli cell nuclei had more than one nucleolus (Fig. 10 ), whereas in control rats multiple nucleoli were only observed at 22 days of age. When present, the nucleolus was frequently associated with the perinuclear heterochromatin clumps (Figs $8 \& 9$ ). Complex heterochromatin bodies were also observed in the most differentiated Sertoli cell nuclei in 45-day-old oestrogen-treated rats (Fig. 11).

The results of the morphometric study are shown in Tables 1 and 2. Oestrogen-treated rats presented increased relative numbers of Sertoli cells, whereas the absolute Sertoli cell number was unchanged.

The nuclei of Sertoli cells in oestrogenized animals were smaller and presented decreased nuclear membrane infoldings and delayed nucleolar development when compared with control ones. The decrease in the heterochromatin clumps from 22 to 45 days of age was slower in oestrogenized than in control rats.

\section{Discussion}

The total number of Sertoli cells per testis was established at 22 days of age and no differences existed with respect to the values found at $\mathbf{4 5}$ days of age in control animals. These results are in

Fig. 6. Sertoli cell nucleus (SCN) from a control rat at 45 days of age. A fully differentiated nucleolus $(\mathrm{Nu})$ and a small perinuclear heterochromatin clump (arrow) can be observed. BM, basement membrane. $\times 10500$.

Fig. 7. Extensive nuclear membrane infoldings (arrowheads) from a 45-day-old control rat. The nucleolus $(\mathrm{Nu})$ and associated heterochromatin (arrow) can also be observed. $\times 10500$.

Fig. 8. Oestrogen-treated rat at 45 days of age showing Sertoli cell nuclei (SCN) located far from the basement membrane (BM), and with a pseudostratified disposition. In the cytoplasm, residual bodies (asterisk) and lipid droplets (L) are present. $\times 4500$. 

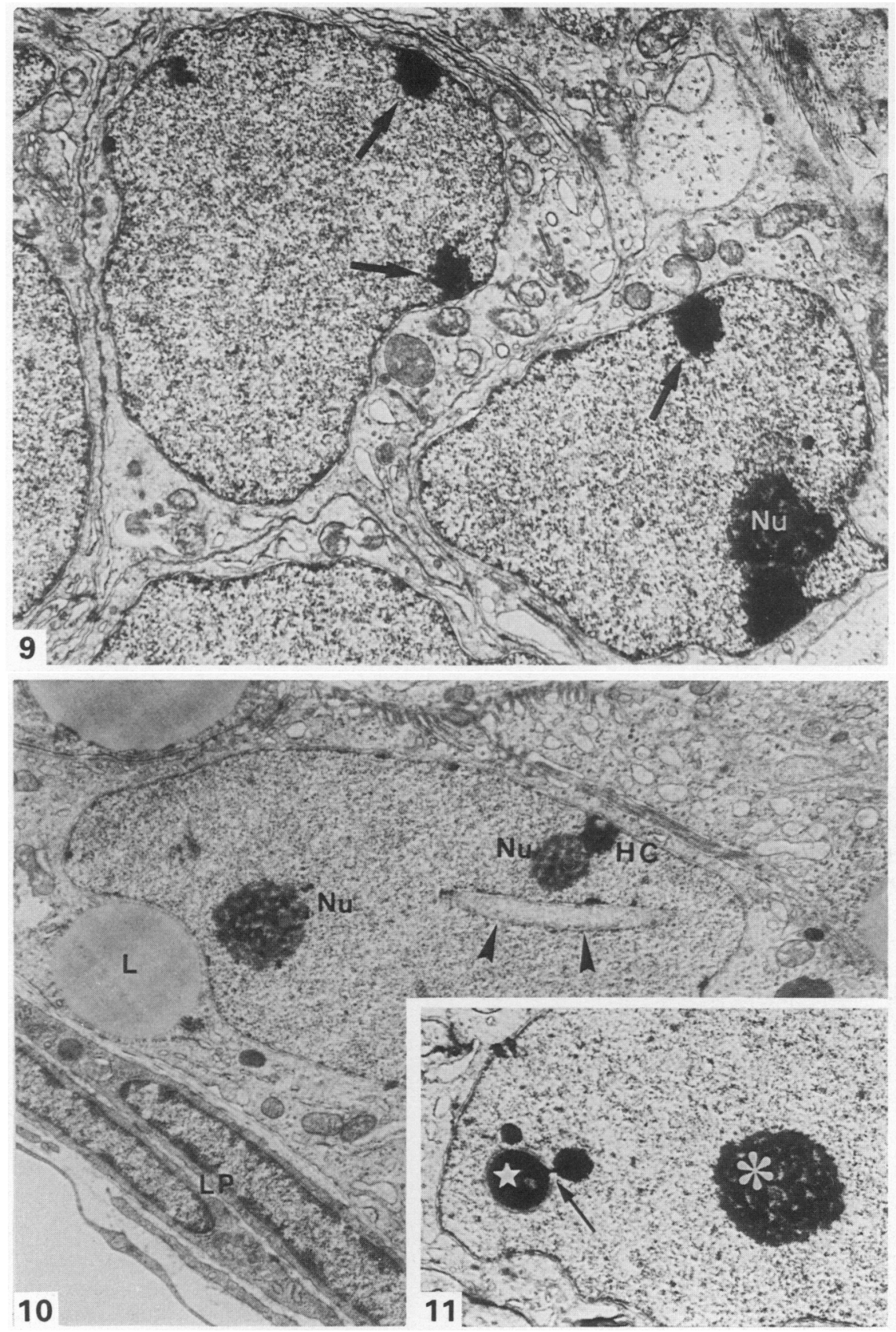

Fig. 9. Sertoli cell nuclei of a 45-day-old oestrogen-treated rat showing perinuclear heterochromatin clumps (arrows) and a developing nucleolus $(\mathrm{Nu})$ associated with perinuclear heterochromatin. $\times 11500$.

Fig. 10. Sertoli cell nucleus presenting nearly normal features in a 45-day-old oestrogen-treated rat. Two nucleoli $(\mathrm{Nu})$, one of them associated with perinuclear heterochromatin $(\mathrm{HC})$, can be seen. A nuclear infolding (arrowheads) and lipid droplets $(\mathrm{L})$ in the cytoplasm are present. LP, lamina propria. $\times 10500$.

Fig. 11. The nucleolus (asterisk) and heterochromatin bodies (star) connected by an electrondense bridge (arrow) can be seen. $\times 12000$. 
Table 1. Number of Sertoli cells in control and neonatally oestrogen-treated rats

\begin{tabular}{|c|c|c|c|c|}
\hline & \multicolumn{2}{|c|}{ 22-day-old rats } & \multicolumn{2}{|c|}{ 45-day-old rats } \\
\hline & Controls & Oestrogenized & Controls & Oestrogenized \\
\hline $\begin{array}{l}\text { No. of Sertoli cell nuclei per tubule } \\
\text { cross-section }\end{array}$ & $39.01 \pm 1.70$ & $44.81 \pm 2.04^{*}$ & $23 \cdot 34 \pm 0 \cdot 74^{*} \dagger$ & $31.00 \pm 2.09^{*}+\ddagger$ \\
\hline $\begin{array}{l}\text { No. of Sertoli cells per } \mathrm{cm}^{3} \text { of } \\
\text { seminiferous tubule }\left(\times 10^{-6}\right)\end{array}$ & $548 \cdot 01 \pm 25 \cdot 10$ & $1120 \cdot 32 \pm 75.06^{*}$ & $43 \cdot 75 \pm 1 \cdot 24^{* \dagger}$ & $143.05 \pm 8 \cdot 15^{*} \dagger \ddagger$ \\
\hline $\begin{array}{l}\text { No. of Sertoli cells per average } \\
\text { testis }\left(\times 10^{-6}\right)\end{array}$ & $32.56 \pm 1.40$ & $31.94 \pm 2.28$ & $33 \cdot 35 \pm 0.98$ & $32 \cdot 17 \pm 2 \cdot 01$ \\
\hline
\end{tabular}

Values are mean \pm s.e.m. for 5 rats/group.

${ }^{*} P<0.05$ compared with value for 22 -day-old controls.

$\dagger P<0.05$ compared with value for 22 -day-old oestrogen-treated animals.

$\ddagger P<0.05$ compared with value for 45 -day-old controls.

Table 2. Morphometric data of the Sertoli cell nuclei from control and oestrogen-treated rats

\begin{tabular}{|c|c|c|c|c|}
\hline & \multicolumn{2}{|c|}{ 22-day-old rats } & \multicolumn{2}{|c|}{ 45-day-old rats } \\
\hline & Controls & Oestrogenized & Controls & Oestrogenized \\
\hline $\begin{array}{l}\text { Mean area of nuclear profiles } \\
\left(\mu \mathrm{m}^{2}\right)\end{array}$ & $14.01 \pm 0.56$ & $10 \cdot 74 \pm 1 \cdot 28^{*}$ & $23.02 \pm 0.51^{*} \dagger$ & $16 \cdot 06 \pm 1 \cdot 60^{*}+t$ \\
\hline $\begin{array}{l}\text { Volume density of } \\
\text { heterochromatin clumps (\%) }\end{array}$ & $2.20 \pm 0.05$ & $2.36 \pm 0.06$ & $0.71 \pm 0.06^{*} \dagger$ & $1.66 \pm 0.07^{*}+t$ \\
\hline $\begin{array}{l}\text { Volume density of nuclear } \\
\text { infoldings }(\%)\end{array}$ & $1 \cdot 11 \pm 0 \cdot 04$ & $0.26 \pm 0.05^{*}$ & $3.12 \pm 0.09 * \dagger$ & $1.64 \pm 0 \cdot 15^{*} \dagger \ddagger$ \\
\hline $\begin{array}{l}\% \text { of nuclear sections showing } \\
\text { nucleoli }\end{array}$ & - & - & $40 \cdot 17 \pm 1 \cdot 80$ & $26 \cdot 50 \pm 2 \cdot 02 \ddagger$ \\
\hline Mean nucleolar diameter $(\mu \mathrm{m})$ & - & - & $1 \cdot 46 \pm 0 \cdot 10$ & $1 \cdot 01 \pm 0.11 \ddagger$ \\
\hline
\end{tabular}

Values are mean \pm s.e.m. for 5 rats/group.

${ }^{*} P<0.05$ compared with value for 22 -day-old controls.

$+P<0.05$ compared with value for 22 -day-old oestrogen-treated animals.

$\ddagger P<0.05$ compared with value for 45-day-old controls.

accord with those of Steinberger \& Steinberger (1971), who reported that Sertoli cell replication ceased before 20 days of age both in vivo and in organ cultures. The "small mitoses" observed by Clermont \& Perey (1957) that they attributed to immature Sertoli cells were not detected after the 15 th day of life. The total number of Sertoli cells was not altered by the neonatal administration of oestrogen. Since important hormonal alterations are present in neonatally oestrogen-treated rats during the early postnatal period (Bellido et al., 1985), it is tempting to suggest that the postnatal Sertoli cell divisions are not dependent on hormonal levels, and the finding that the replication pattern of Sertoli cells was retained in organ cultures in the absence of extragonadal factors (Steinberger \& Steinberger, 1971) supports this view. However, the smaller tubular volume present in oestrogen-treated rats (Gaytan et al., 1986) results in the relative numbers of Sertoli cells being greater in oestrogen-treated rats than in control ones. The pseudostratified distribution of Sertoli cell nuclei in the former seems to reflect not only a lack of cell maturation but an effect of the reduced tubular volume. Increased numbers of Sertoli cell nuclei per tubule cross-section have been reported for many testicular disorders in man (Nistal et al., 1982) and in rats after experimental treatments (Murphy, 1965). 
In spite of the presence of numerous Sertoli cell alterations in many human testicular disorders (Nistal et al., 1982; Paniagua et al., 1985) no significant changes in the Sertoli cell number have been reported. In the present study, degenerating Sertoli cells were only occasionally found in control or oestrogen-treated rats, although a great number of degenerating germ cells was found in neonatally oestrogenized rats (Gaytan et al., 1986). On the other hand, changes in the number of Sertoli cells, have been reported in immature Sertoli cell cultures after FSH treatment (Griswold et al., 1977) and in prepubertal rats after antiandrogen treatment with flutamide (Viguier-Martinez et al., 1983). The factors regulating postnatal Sertoli cell replication remain unclear, and the contribution of the postnatal cell divisions to the adult Sertoli cell population is not well established.

Nevertheless, all the characteristics studied here for nuclear maturation (mean nuclear area, heterochromatin clump and nuclear membrane infolding volume densities, as well as the nucleolar development) were severely affected by the oestrogen treatment. The dependence of maturation of Sertoli cells on gonadotrophins and androgens has been well established (Chemes et al., 1979; Sanborn et al., 1986). The effects of FSH on Sertoli cell development remain controversial. Some authors have found that treatment of immature rats with FSH produces a precocious nucleolar development (Solari \& Fritz, 1978), but others report that FSH withdrawal with antiserum did not affect significantly the nucleolar development (Chemes et al., 1979), although no data on nucleolar size were provided. Nucleolar development was delayed in neonatally oestrogen-treated rats. In addition to the smaller nucleolar size in these animals, more than one nucleolus per Sertoli cell nucleus and frequent association of the nucleoli to the perinuclear heterochromatin clumps were observed in 45-day-old oestrogen-treated rats. These features correspond to the first stages of nucleolar development in Sertoli cells (Ramos \& Dym, 1979).

The increase in the heterochromatin clump volume density was significant only at 45 days of age. Ramos \& Dym (1979) found that the number of heterochromatin clumps reaches a peak between 21 and 35 days of age, and decreases after this age. The significance of this biphasic pattern is unclear, but it must be related to the rapid morphological changes that occur at this age in the Sertoli cells (Ramos \& Dym, 1979). The increased values found for the heterochromatin volume density in 45-day-old oestrogen-treated rats seem therefore to be due to a lack of the normal disappearance of these structures, rather than to a greater formation.

It has been reported that there are gonadotrophin and testosterone increases in immature rats at about 20-45 days of age (Miyachi et al., 1973; Lee et al., 1975). At this time, important events occur in the developing testes, such as Leydig cell differentiation, rapid tubular growth and completion of the first spermatogenic wave (Mills et al., 1977; Chemes et al., 1979). The nuclear maturational changes of Sertoli cells are coincident with these high hormonal levels. It is generally agreed that the association of FSH and testosterone is needed for Sertoli cell function in immature rats (Hansson et al., 1976). In the adult rat, androgens seem to be the most important hormones for testicular function (Bressler, 1976). Neonatally oestrogenized rats have an altered hormonal pattern during prepubertal development (Aguilar et al., 1984; Bellido et al., 1985), and Leydig cells are not differentiated at 45 days of age in these animals (Gaytan et al., 1986). Steroid hormones alter the nuclear structure in many organs, such as the central nervous system (Cohen et al., 1984) and the male sex accessory glands (Arnold et al., 1983), and a possible direct effect of oestrogens cannot be excluded from the present results. However, the alterations present in neonatally oestrogen-treated rats are very similar to those reported by other authors after hormone exclusion by treatment with antisera to LH or FSH (Chemes et al., 1979). Treatment with gonadotrophins can reverse, at least, in part, the testicular alterations induced by oestrogen (Ohta, 1977). The impaired nuclear development of Sertoli cells found in oestrogen-treated rats therefore seems to be due to the hormonal alterations induced by the neonatal oestrogen administration, rather than to a direct effect of oestrogens.

The criteria used here as indicators of Sertoli cell nuclear maturation can be easily quantified and have been shown to be sensitive to hormonal alterations (Bressler, 1976; Chemes et al., 1979). These measures could therefore be useful for analysing the responses of Sertoli cells to different 
experimental conditions, since quantitative morphological features may be easily correlated with biochemical and functional responses.

The work has been possible through grant 3344 from the 'Comision Asesora de Investigación Cientifica y Técnica'.

\section{References}

Aguilar, E., Tejero, A., Vaticón, M.D. \& FernándezGalaz, C. (1984) Dissociation of luteinizing hormone and follicle-stimulating hormone control mechanisms in male and female rats by neonatal administration of estradiol benzoate or testosterone propionate. Horm. Res. 19, 108-116.

Arnold, C., Gulbenkian, S., Carmo-Fonseca, M. \& DavidFerreira, J.F. (1983) Androgen dependent changes in nuclear ultrastructure. A stereological study on rat ventral prostate and seminal vesicle. Biol. Cell. 47 , $161-170$.

Bellido, C., Gaytan, F., Aguilar, R., Pinilla, L. \& Aguilar, E. (1985) Prepubertal reproductive defects in neonatal estrogenized male rats. Biol. Reprod. 33, 381-387.

Bressler, R.S. (1976) Dependence of Sertoli cell maturation on the pituitary gland in the mouse. Am. J. Anat. 147, 447-456.

Bugge, H.P. \& Plöen, L. (1986) Changes in the volume of Sertoli cells during the cycle of the seminiferous epithelium in the rat. $J$. Reprod. Fert. 76, 39-42.

Chemes, H.E., Dym, M. \& Raj, H.G.M. (1979) Hormonal regulation of Sertoli cell differentiation. Biol. Reprod. 21, 251-262.

Clermont, Y. \& Perey, B. (1957) Quantitative study of the cell population of the seminiferous tubules in immature rats. Am. J. Anat. 100, 241-269.

Cohen, R.S., Chung, S.K. \& Pfaff, D.W. (1984) Alteration by estrogen of the nucleoli in nerve cells of the rat hypothalamus. Cell Tissue Res. 235, 485-489.

Elias, H. \& Hyde, D.M. (1980) An elementary introduction to stereology (quantitative microscopy). Am. J. Anat. 159, 412-446.

Fawcett, D.W. (1975) Ultrastructure and function of the Sertoli cell. In Handbook of Physiology, Section 7, vol. V, Male Reproductive System, pp. 21-55. Eds D. W. Hamilton \& R. O. Greep. American Physiological Society, Washington, D.C.

Flickinger, C.J. (1967) The postnatal development of the Sertoli cells of the mouse. Z. Zellforsch, mikrosk, Anat. 78, 92-113.

Gaytan, F., Pinilla, L., Aguilar, R., Lucena, M.C. \& Paniagua, R. (1986) Effects of neonatal estrogen administration on rat testis development with particular reference to Sertoli cells. J. Androl. 7, 112-121.

Griswold, M.D., Solari, A., Tung, P.S. \& Fritz, I.B. (1977) Stimulation by follicle stimulating hormone of DNA synthesis and mitosis in cultured Sertoli cells prepared from testis of immature rats. Molec. cell. Endocr. 7, 151-165.

Hansson, V., Djoseland, O., Torgensen, O., Ritzen, E.M., French, F.S. \& Nayfeh, S.N. (1976) Hormones and hormonal target cells in the testis. Andrologia 8, 195-202.
Hon, C.A., Gardner, P.J. \& Leuschen, M.P. (1983) Immunocytochemical staining of isolated rat Sertoli cells for anti-FSH. Am. J. Anat. 167, 441-450.

Leblond, C.P. \& Clermont, Y. (1952) Definition of the cycle of the seminiferous epithelium in the rat. Ann. N.Y. Acad. Sci. 55, 548-573.

Lee, V.W.K., de Kretser, D.M., Hudson, B. \& Wang, C. (1975) Variations in serum FSH, LH and testosterone levels in male rats from birth to sexual maturity. J. Reprod. Fert. 42, 121-126.

Mills, N.C., Mills, T.M. \& Means, A.R. (1977) Morphological and biochemical changes which occur during postnatal development and maturation of the rat testis. Biol. Reprod. 17, 124-130.

Miyachi, Y., Nieschlag, E. \& Lipssett, M.B. (1973) The secretion of gonadotropins and testosterone by the neonatal male rat. Endocrinology 92, 1-5.

Murphy, H.D. (1965) Sertoli cell stimulation following intratesticular injections of FSH in the hypophysectomized rat. Proc. Soc. exp. Biol. Med. 118, 1202-1205.

Nistal, M., Paniagua, R., Abaurrea, M.A. \& Santamaria, L. (1982) Hyperplasia and immature appearance of Sertoli cells in primary testicular disorders. Human Pathol. 13, 3-12.

Ohta, Y. (1977) Response of testis to androgen and gonadotropins in neonatally estrogenized and androgenized mice. Endocrinol. jap. 24, 287-294.

Ohta, Y. \& Takasugi, N. (1974) Ultrastructural changes in the testes of mice given neonatal injections of estrogen. Endocrinol. jap. 21, 183-190.

Paniagua, R., Amat, P., Nistal, M. \& Martin, A. (1985) Ultrastructural changes in Sertoli cells in ageing humans. Int. J. Androl. 8, 295-312.

Parvinen, M. (1982) Regulation of the seminiferous epithelium. Endocr. Rev. 3, 404-417.

Ramos, A.S. \& Dym, M. (1979) Ultrastructural differentiation of rat Sertoli cells. Biol. Reprod. 21, 909-922.

Ritzen, E.M., Hansson, V. \& French, F.S. (1981) The Sertoli cell. In The Testis, pp. 171-194. Eds H. Burger \& D. M. de Kretser. Raven Press, New York.

Sanborn, B.M., Wagle, J.R., Steinberger, A. \& GreerEmmert, D. (1986) Maturational and hormonal influences on Sertoli cell function. Endocrinology 118, 1700-1709.

Solari, A.J. \& Fritz, I.B. (1978) The ultrastructure of immature Sertoli cells: maturation-like changes during culture and the maintenance of mitotic potentiality. Biol. Reprod. 18, 329-345.

Steinberger, A. \& Steinberger, E. (1971) Replication pattern of Sertoli cells in maturing rat testis in vivo and in organ culture. Biol. Reprod. 4, 84-87.

Viguier-Martinez, M.C., Hochereau de Reviers, M.T., Barenton, B. \& Perreau, C. (1983) Effect of a 
non-steroidal antiandrogen, flutamide, on the hypothalamo-pituitary axis, genital tract and testis in growing male rats: endocrinological and histological data. Acta endocr., Copenh. 102, 299-306.

Vitale, R., Fawcett, D.W. \& Dym, M. (1973) The normal development of the blood-testis barrier and the effects of clomiphene and estrogen treatment. Anat. Rec. 176, 331-344.
Vogel, D.L., Gunsalus, G.L., Bercu, B.B., Musto, N.A. \& Bardin, C.W. (1983) Sertoli cell maturation is impaired by neonatal passive immunization with antiserum to luteinizing hormone-releasing hormone. Endocrinology 112, 1115-1121.

Wing, T.Y. \& Christensen, A.K. (1982) Morphometric studies on rat seminiferous tubules. Am. J. Anat. 165, 13-25.

Received 30 July 1986 